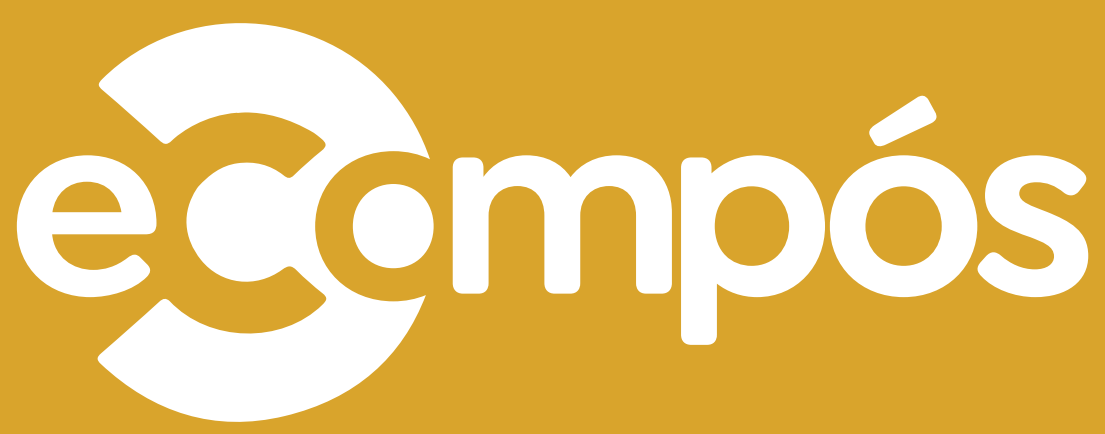

Revista da Associação Nacional dos Programas de Pós-Graduação em Comunicação

ISSN 1808-2599, v. 24, jan-dez,

publicação contínua, 2021, p. 1-18.

doi.org/10.30962/ec.2332

\title{
Práticas de ressignificação ou de violação dos arquivos?
}




\section{/ resumo}

Como podemos nos aproximar de um arquivo imagético sem desfigurá-lo? Como reempregá-lo em novas obras, respeitando sua opacidade e ambiguidade? Este trabalho aborda a recorrência dos arquivos em certa produção documentária contemporânea e o modo como determinadas escolhas de montagem terminam por violentá-los, comprometendo assim novos entendimentos do passado neles registrado. Como sugere Didi-Huberman, uma vez que os eventos e temporalidades fixados nas imagens jamais despontarão integralmente, sua reutilização por novos diretores deve ser conjugada com um trabalho de imaginação histórica que lhes possibilite entrever o que nelas permanece latente.

Palavras-chave: Documentário. Imagens de arquivo. Ressignificação. Montagem.

\section{¿Prácticas de reapropiación o violación de archivos?}

¿Cómo acercarnos a un archivo de imagen sin desfigurarlo? ¿Cómo reutilizarlo en nuevas obras, respetando su opacidad y ambigüedad? Este trabajo plantea la recurrencia de los archivos en una determinada producción documental contemporánea y la forma en que determinadas elecciones de edición terminan por violarlos, comprometiendoasí la comprensión del pasado que en ellos se registra. Como sugiere Didi-Huberman, dado que los eventos y temporalidades fijados en las imágenes nunca emergerán del todo, su reempleo por nuevos directores debe combinarse con un trabajo de imaginación histórica que les permita vislumbrar lo que en ellas queda latente.

Palabras clave: Documental. Imágenes de archivo. Apropiación. Montaje.

\section{Practices of repurposing or violation of archives?}

How could we approach an archive image without disfiguring it? How could we repurpose it in new films, respecting its opacity and ambiguity? This paper investigates the recurrence of the archives in a certain contemporary documentary practice and the way how some montage choices end up violating them, thus compromising new understandings of the past crystallized in them. As Didi-Huberman suggests, once that the events and temporalities registered in the images will never emerge in full, their repurpose by new directors should be combined with a work of historical imagination, so that they can perceive what remains latent in them.

Keywords: Documentary. Archive images. Repurpose. Montage. 


\section{Laecio R. de Aquino RODRIGUES}

Doutor pelo Programa de Pós-Graduação

em Multimeios da Universidade Estadual de

Campinas (Unicamp). Professor do Departamento

de Comunicação Social e do Programa de

Pós-Graduação em Comunicação (PPGCOM) da

Universidade Federal de Pernambuco (UFPE).

Universidade Federal de Pernambuco, Recife, Pernambuco, Brasil.

E-mail: laecio.ricardo@ufpe.br

\section{ORCID}

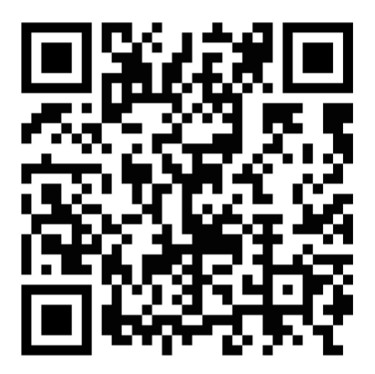




\section{Introdução}

Ao revisar os apontamentos de diferentes autores, o objetivo deste trabalho é discutir o tratamento conferido aos arquivos audiovisuais em alguns documentários contemporâneos que investem em sua retomada', mediante operações como a montagem e procedimentos como a colorização, a sonorização, o reenquadramento e o ralenti, dentre outros; recursos que, numa primeira avaliação, almejariam a produção de novas legibilidades históricas. Queremos avaliar em que medida, nessas obras, tais práticas fomentam novos entendimentos do passado ou contribuem, antes, para um embotamento e/ou uma violação do arquivo e, consequentemente, para uma menor compreensão dos eventos abordados. Para fins didáticos, adotaremos o seguinte percurso: primeiramente, desejamos ponderar o que seria um arquivo e, sobretudo, um arquivo imagético; em seguida, definiremos o que designamos como um filme de arquivo; por fim, nos interessa mensurar as implicações da montagem nessa prática.

Nesta introdução, parece-nos pertinente também mencionar, ainda que resumidamente, o embate da ciência histórica com a imagem enquanto ferramenta viável ou não para a articulação de saberes históricos. Embora relativamente antigo, tal impasse ainda divide a comunidade acadêmica. Como forma de situar o leitor em sua complexidade, indicamos dois títulos que reavaliam essa polarização: afinal, como se aproximar de uma imagem e a partir dela construir um pensamento sobre o passado? São eles: Testemunha ocular, livro de Peter Burke (2004) e uma espécie de revisão geral do debate, sobretudo em relação às fontes pictóricas; e Imagens apesar de tudo, de Didi-Huberman (2012), instigante ensaio sobre os excessos do que poderíamos chamar de iconofobia e iconofilia, entendidas como a rejeição da evidência imagética ou a sua sacralização, polaridades igualmente problemáticas ao seu justo manuseio.

Porfim, duas outras observações são relevantes nesta introdução: o que designamos como retomada dos arquivos, ressaltamos, não é prática exclusiva do documentário, embora os exemplos mais potentes, ao nosso ver, despontem nesse domínio audiovisual. De qualquer forma, lembramos que, além do cinema, certa produção televisiva e/ou voltada para a internet se utiliza desse recurso. Por outro lado, mesmo no campo do documentário, esta também não é uma prática recente, embora se converta numa forte tendência contemporânea (BARON, 2014)².

Voltemos, agora, às perguntas norteadoras do nosso percurso: o que é um arquivo e o que seria um filme de arquivo? o que repousaria nos registros do passado como uma espécie de mensagem endereçada ao futuro? E como melhor abordá-la? Segundo a historiadora Arlette Farge (2009), o arquivo seria aquilo que nos atrai e nos desconcerta pelos seus efeitos de realidade e de opacidade. Diante dele, um olhar destreinado poderia julgar ter descoberto uma "verdade plena"; mas, como alerta Farge (2009), ele é apenas uma brecha no tecido dos dias e não um continente de sentidos. Portanto, todo arquivo seria marcado pela incompletude, e a euforia pela sua descoberta não pode nos apartar da cautela no seu manejo. Assim,

\footnotetext{
1 No ensaio, fazemos uma apreciação de títulos díspares entre si, mas que revisitam em sua abordagem eventos notáveis da cobertura jornalística ou episódios históricos de relevo; são obras que revolvem, portanto, uma matéria-prima factual. Na investigação aqui proposta, também diverge a extensão dos comentários que dirigimos a cada filme; seja porque o nosso interesse analítico poderá focar apenas uma sequência de determinado documentário, seja porque nos sentimos mais estimulados a avançar na tessitura de uma ou outra produção. De qualquer forma, nos parece natural que um trabalho que agrega um corpus extenso e com clara limitação espacial (número de páginas pré-definido) evite mergulhos aprofundados em prol da unidade argumentativa. Assim, nosso recorte reúne o "filmete" Zapruder Film (1963), de Abraham Zapruder; e os seguintes longas: Ônibus 174 (2002), de José Padilha; A imagem que falta (2013), de Rithy Panh; a série Apocalipse - A Primeira Guerra Mundial (2014), de Isabelle Clarke e Daniel Costelle; a série da BBC Auschwitz - Os nazistas e a solução final (2005); Eles não envelhecerão (2018), de Peter Jackson; e Democracia em vertigem (2019), de Petra Costa. Tais títulos, reiteramos, são convocados em conformidade com os temas e questões introduzidos no ensaio. Por fim, uma última observação nos parece pertinente: no texto investigamos obras que promovem intervenções em tomadas que possuem relação icônica e indicial com um referente histórico claro; não estamos, portanto, no campo da chamada deepfake, onde o trabalho de manipulação e simulação opera com imagens sem referencialidade (um artifício sem correspondência direta no passado). Por isso, não adentramos nessa discussão, que tem sua urgência, mas demandaria outras referências fílmicas e teóricas.
}

2 A produção bibliográfica sobre o tema também é crescente. Para ilustrar tal progressão, destacamos três títulos da tradição anglo-saxônica: Films beget films, estudo de Jay Leyda (1964); o volume Recycled images, de William Wees (1993); e o recente The archive effect, de Jaimie Baron (2014). 
Farge (2009) nos dirá que o arquivo é aquilo que nos invade com aparentes certezas para depois instalar desconfianças; e que é preciso acolhê-lo como evidência e não como prova.

Feitas essas considerações, passemos a indagação: o que seria um filme de arquivo? São obras que insuflam e revigoram imagens/sons produzidos por outros e em tempos passados; registros esmaecidos e talvez esquecidos, confinados nos acervos públicos e privados das cinematecas e emissoras, bem como no espólio de muitas famílias. Portanto, são produções que injetam vitalidade nesses registros, vislumbrando neles diferentes arranjos e camadas de sentidos (o trabalho de ressignificação), e, não raro, promovendo novos entendimentos históricos. Para fins didáticos, e por ter maior afinidade com o debate, vamos nos referir, preferencialmente, apenas ao arquivo imagético ${ }^{3}$, embora estejamos cientes da importância dos arquivos sonoros nessa prática.

Uma imagem, lembremos, é um campo de conflitos semânticos, passível sempre de novas atualizações. Ela não é um objeto cujos sentidos se cristalizam de forma definitiva; antes, sofre oscilações com o transcorrer do tempo, modificações que carecem de sedimentação e de outros olhares que aceitem indagá-las. Para descobrir essas latências não evidentes no contexto de sua produção, é preciso interrogálas, colocá-las em outros fluxos e enfrentar sua opacidade. Didi-Huberman $(2012,2015)$ sugere que apenas na montagem novos sentidos e conexões podem ser identificados. Essa tarefa, contudo, não visa teleologias; em outros termos, pode-se sempre retomar uma imagem e redistribui-la em novos arranjos, entrevendo assim diferentes camadas semânticas. Em outro ensaio, Bernardet (2004) utilizará a expressão migração das imagens para destacar o que nelas existe de indeterminado e suas infinitas possibilidades de recombinações.

Sobre os múltiplos sentidos presentes numa imagem, Comolli e Lindeperg (2010, p. 337) nos dizem algo similar:

\begin{abstract}
A gravação das visibilidades e das temporalidades pela máquina cinematográfica 'capta' ou revela relações, ligações que não havíamos necessariamente visto ou compreendido no momento da tomada. [...] A natureza da imagem cinematográfica supõe e acarreta a impressão de elementos do mundo que não havíamos notado ou, menos ainda, calculado: alguma coisa de um 'real' ainda ilegivel, em gestação, em devir, portador de uma leitura e de um sentido futuros. Algo da dimensão do latente revelase então. É a potência do cinema que está em jogo aqui. Um certo estado do mundo, do movimento do mundo, é ao mesmo tempo suscitado e gravado pelo cinema.
\end{abstract}

Há nessa passagem uma proximidade com aquilo que Walter Benjamin (2012; 2017), em alguns textos, designava de condição de vidência da fotografia. Algo como se a imagem fosse portadora dos futuros possiveis, das demandas sonhadas por gerações anteriores. Em outros termos, ela não nos informaria o futuro que é (ou aquilo que se tornou o presente do qual somos contemporâneos); antes, ela parece portar as promessas não consolidadas, os sonhos soterrados pelas engrenagens da história. Por isso, DidiHuberman (2015) nos dirá: diante de uma imagem estaríamos diante da voragem do tempo e perante essas expectativas não concretizadas e que solicitam a nossa acolhida, a nossa solidariedade 4 .

Em resumo, como Farge (2009) destacou, fragilidade e inexatidão são propriedades comuns aos arquivos do passado - e, portanto, também aos registros audiovisuais. Devemos, assim, aceitar que o documento, antes de tudo, é falta e nunca a recuperação integral de um evento ou trajetória. Por isso

3 Talvez caiba aqui fazer breve distinção entre o que seria um arquivo que já circulou publicamente (e que, de algum modo, se tornou conhecido) e aquilo que se designa de "found-footage", expressão que parece se referir a registros até então desconhecidos, produzidos em condições amadoras (no âmbito privado e/ou familiar) e que, encontrados por um diretor e submetidos a operações de remontagem, permitem novas legibilidades históricas (WEES, 1993).

4 Didi-Huberman (2012) insistirá assim no caráter profético da imagem. No entanto, uma vez que os eventos e temporalidades nela fixados jamais despontarão integralmente, a prática da montagem deve ser conjugada com um trabalho de imaginação histórica, que nos permita entrever o que se esconde na sua opacidade. 
mesmo, o cuidado no seu manuseio é essencial para não burlarmos esse aspecto constitutivo ou ontológico do arquivo, para que distorções sejam evitadas ou ponderadas no presente da prática documentária. Concluída a revisão, podemos agora avançar no tema central do ensaio.

\section{Arquivo, montagem, legibilidade?}

Nosso percurso se inicia com a reavaliação de um texto sobre o plano-sequência, escrito por Pasolini em 1967. No ensaio, o diretor italiano escreve impactado pelo chamado Zapruder Film, um filme curtíssimo, registrado por Abraham Zapruder, e que casualmente documenta o assassinato de John Kennedy, em Dallas, em novembro de 1963. Uma tomada precária (a captação não é profissional) e exígua, mas com duração suficiente para tornar uma nação obcecada em torno da tragédia presidencial. Uma vez revisto, o que o curta pode nos dizer sobre o fatídico episódio, o que nos daria a ver? E que experiência e entendimento sobre o manuseio dos arquivos nos facultaria?

Ponderando o filmete e o seu visionamento, Pasolini $(1981)^{5}$ reconhece que pouco vemos daquela funesta manhã. Ou seja, quase nada retorna nas imagens. Ao mesmo tempo, a tomada é tudo o que dispomos do episódio em termos de evidência visual. Para nos permitir acessar o evento em questão, Pasolini sugere que seria necessária a existência de inúmeros planos-sequência e de múltiplos pontos de vista, registrados simultaneamente e que nos permitissem uma imersão visual daquela manhã em Dallas. Ainda assim, sobre esse material bruto imaginário, seria imprescindivel a realização de um trabalho de montagem.

A partir daqui, Pasolini (1981) migra de tema: abandona os apontamentos sobre o plano-sequência e termina por esboçar um pensamento sobre a montagem. Segundo ele, a montagem, na obra fílmica, realizaria um trabalho semelhante ao da morte: posto que toda existência é inapreensivel na sua completude e porta cargas de imprevisibilidade, é a morte que lhe dá um "fechamento"; ou seja, concluída a trajetória de alguém, ela permitiria narrá-la ou interpretá-la (o que nós poderíamos chamar de positividade da morte). Desse modo, conclui Pasolini (1981), embora toda montagem seja redutora (envolva seleção, exclusão, hierarquização), ela é uma operação necessária e o artista deve enfrentá-la - ele deve definir o melhor percurso de visionamento da obra pelo espectador, ciente de que o seu esforço não restituirá a íntegra dos eventos, ao mesmo tempo em que promoverá triagens inevitáveis. Montar, portanto, é possibilitar visibilidades, mas também gerar ocultamentos.

Avaliemos, mais detidamente, o trabalho da montagem, sobretudo quando o emprego de certos recursos nessa operação parece demandar do arquivo bem mais do que ele poderia informar, a ponto de descaracterizá-lo. Deixamos Pasolini de lado e voltamo-nos ao Zapruder Film: nas décadas seguintes, foram muitos os especialistas que retomaram esse filmete no intuito de perscrutá-lo e de fazê-lo "falar mais"; ou seja, de exigir que ele revele pormenores sobre a morte presidencial ${ }^{6}$. Nessas práticas, vislumbramos um

5 Embora o ensaio seja de 1967, somente ganhou tradução portuguesa em 1981, com o lançamento do livro Empirismo hereje.

6 o material de Abraham Zapruder não é o único registro daquela manhã em Dallas, mas é o que melhor documenta o momento dos disparos. No decorrer do tempo, visando "maiores visibilidades", o registro ganhou ampliação para outras bitolas, passou por restauro e intervenção digital no sentido de "limpar" a granulação e o tremor da imagem. Uma rápida pesquisa do mesmo por sites de armazenamento nos revelam diferentes versões: algumas acompanhadas de narração e sonorização; outras com efeitos de ralenti e de repetições; edições intercaladas com animação e até efeitos em 3D. Isso nos leva a duas conclusões: as intervenções parecem "demandar" do material original informações nele não contidas (um esforço para fazer emergir a íntegra do evento); e, tendo em vista as muitas versões em circulação, constitui tarefa árdua encontrar o registro original de Zapruder. Uma revisão e análise dos vídeos existentes sobre o assassinato de Kennedy pode ser encontrada no livro de Bugliosi (2007), com especial atenção ao Zapruder Film. Para os interessados, indicamos algumas versões reeditadas, as quais podem ser acessadas em: https://www.youtube.com/ watch?v=Zmz4lz6l8Fs (high quality); https://www.youtube.com/watch?v=eqzJQE8LYrQ (versão com zoom e desacelerada); https://www.youtube.com/ watch?v=lj43Lo8E1zQ (versão em HD); https://www.youtube.com/watch?v=PfSXkfV_mhA (versão acrescida de animação). Dois outros endereços trazem informações adicionais: em http://assassinationresearch.com/zfilm/, pode-se conferir o Zapruder Film frame a frame; já em http://www.jfklancer. com/History-Z.html, temos uma pequena história do destino do famoso registro. Em https://www.youtube.com/watch?v=0zsk4DSzQ2s, oriundo dos arquivos do grupo Time, acompanhamos o relato do ex-editor da publicação, Richard Stolley, sobre como ele conseguiu negociar com Zapruder os direitos de exibição do filmete, até então inédito para o público. Todos os links foram acessados em 21 de julho de 2020. 
empreendimento que entende como déficit o que designamos de lacunaridade ou incompletude do arquivo. Em outros termos, ao observar tais apropriações, não testemunhamos uma operação de remontagem que visa localizar latências. Ao contrário, nos deparamos com uma intervenção que viola o arquivo e desrespeita a fenomenologia da tomada (as condições de apreensão do registro). Assim, ao revisitar os diferentes destinos conferidos ao Zapruder Film, é impossivel não nos lembrarmos dos apontamentos de Didi-Huberman (2012) em Imagens apesar de tudo sobre o uso indevido das quatro fotografias do interior de um campo de extermínio nazista - produzidas em circunstâncias extraordinárias por integrantes do Sonderkommando ${ }^{7}$, numa tentativa de comunicar ao mundo algo do horror ali vivido, tais imagens foram por décadas objeto de manipulação, o que nos impedia de percebermos sua excepcionalidade e o risco enfrentado por aqueles que as registraram. Em síntese, para o autor, cada manuseio indevido dessas fotos nos apartava ainda mais de sua singularidade e de um melhor entendimento do passado.

Mas se mencionamos o exemplo do Zapruder Film é apenas para reiterar que, no presente, a prática de manipular os arquivos para "suprir" sua lacunaridade (ou de silenciá-los quando são explícitos demais) parece ter sido adotada em alguns documentários - integralmente ou em trechos específicos. Assim, seu emprego despontaria na sequência final de Ônibus 174 (2002), de José Padilha; na série Apocalipse - A Primeira Guerra Mundial (2014), de Isabelle Clarke e Daniel Costelle; na série da BBC Auschwitz - Os nazistas e a solução final (2005); no filme Eles não envelhecerão (2018), de Peter Jackson; e num polêmico plano utilizado em Democracia em vertigem (2019), de Petra Costa, dentre outros títulos. Ao cotejar esses exemplos, desejamos investigar as implicações desse fenômeno para o saber histórico que resulta do emprego de arquivos violados.

Contudo, se a montagem é a etapa onde parte dessa adulteração é exercida, culminando assim numa desfiguração dos arquivos e no eventual logro do espectador, intuímos ser interessante ampliar a reflexão sobre essa fase da realização fílmica. Afinal, como apontou Pasolini (1981) em seu texto, embora toda montagem seja redutora e priorize leituras, ela é uma operação incontornável. Mas como aderir a uma montagem historicamente responsável? ${ }^{8}$

Fundamento central nas artes do século XX, a montagem pressupõe a junção/articulação de fragmentos heterogêneos, resultando a obra num arranjo complexo e portador de novos sentidos (portanto, ela não é um conceito exclusivo do campo cinematográfico). Mais do que uma técnica, ela seria um princípio criativo e ilustraria um exercício do pensamento, suscitando igualmente no destinatário da obra um trabalho de intelecção - o seu engajamento crítico durante a fruição artística (AMIEL, 2011).

7 Denominação dada aos prisioneiros recrutados no campo, judeus em sua maioria, para a execução de tarefas consideradas abjetas pelos soldados alemães, tais como a limpeza das câmaras de gás e a cremação dos corpos. Uma vez que a maior parte das vítimas eram judias, percebe-se a perversidade evidente no recrutamento.

8 Embora a expressão aqui utilizada pareça sugerir uma espécie de interdito no decorrer da abordagem, reiteramos que essa não é a nossa proposta. Em outras palavras, não queremos ser dogmáticos e/ou postular regras, mas sim identificar e elucidar alguns usos das imagens de arquivo que consideramos questionáveis. Seja por desfigurá-las, alterando sua fenomenologia e/ou comprometendo as relações estabelecidas entre aqueles que filmaram e/ou foram filmados, seja por desconsiderar a lacunaridade própria dos arquivos e, assim, ceder aquilo que designaremos mais à frente como um desejo de visibilidade total característico da economia do visível na contemporaneidade. E tal exercício analítico, evidentemente, não pode ser feito sem o recrutamento dos exemplos fílmicos e sua problematização. Desse modo, se nos parece legítimo dizer que o acervo audiovisual da humanidade se encontra permanentemente disponível para novos exercícios de montagem. Por outro lado, acreditamos que é igualmente justo indicar que tal prática, quando não antecedida de reflexão e/ou apenas norteada pelo espetáculo, pode ter efeitos deletérios e fomentar leituras históricas distorcidas. E acrescentamos: os artifícios e manipulações empregados, além de não serem percebidos pela audiência como uma decisão arriscada, muitas vezes são também celebrados no circuito midiático como uma "virtude técnica". Apenas para citar um exemplo: Eles não envelhecerão, filme de Peter Jackson representativo dos impasses abordados no ensaio, foi objeto de aclamação nos veículos jornalísticos (nacionais e estrangeiros) que consultamos nos meses posteriores ao seu lançamento, sendo louvado pelo seu "triunfo artístico". Igual elogio se repetiu mesmo num fórum especializado e com a participação de uma audiência cinéfila experiente (www.makingoff.org). Ou seja, tais produções são antes objeto de celebração do que de questionamento, o que atestaria, assim, a urgência do nosso empreendimento crítico. 
Na tradição formalista do cinema, o trabalho do diretor visa reelaborar e dar sentido à matéria apreendida pela câmera, pois esta seria muda - lembremos, com Eisenstein (2002a, 2002b), que o real é sempre objeto de construção/intepretação e não de deferência. Ou seja, o cinema só se converteria em arte quando intervém e transforma o material bruto, quando um ímpeto criativo a ele se impõe. No território do documentário, todavia, tal premissa exige cautela. É fato que, em muitos títulos dessa tradição, a montagem adquire um peso relevante - não raro, como uma etapa de recuperação de uma obra julgada inviável. Mas se, nesses casos, a montagem desponta como uma operação salvadora, é preciso lembrar que, em se tratando do manuseio de arquivos com a finalidade de articular um saber histórico ou de promover investigações sobre um episódio factual de relevo, acreditamos que o seu trabalho não pode incorrer em distorções e provocar entendimentos redutores.

Em resumo: se toda edição implica em seleções e cesuras inevitáveis, é preciso discernir entre as práticas de montagem que se esforçam por minimizar as perdas, valorizando o material registrado e concedendo ao espectador a possibilidade de julgar sem ser conduzido por manipulações excessivas, daquelas que promovem interferências regulares e reconstroem os sentidos ao sabor da vontade do diretor/ editor. Duração e ambiguidade, de um lado; onipotência, do outro. Lembremos que o gesto imprudente na edição não maltrata apenas o material bruto (tomadas com valor de evidência histórica); ele sugere também indiferença pelo espectador, que precisa se esquivar dos discursos fechados e lidar com fatias reduzidas para entender questões complexas?.

\section{A retomada dos arquivos, a (im)potência da montagem}

Mas como lidar com a imagem sem tudo dela demandar, como manusear o arquivo sem desfigurálo? Iniciamos este segmento com uma inversão: com a revisão de um título que consideramos exemplar neste debate (virtuoso em suas escolhas), para depois nos dedicarmos aos documentários que parecem exigir demais dos registros do passado; ou que, numa atitude oposta, optam por silenciar o arquivo quando este é muito explícito.

Parte da obra de Rithy Panh, diretor cambojano radicado na França, é marcada pelo que poderíamos designar, em termos narrativos, de uma primazia do eu (são filmes que relatam uma experiência coletiva e familiar, recapitulada pelo ponto de vista do diretor, que centraliza a tarefa enunciativa) e por uma reflexão sobre o testemunho e a potência dos arquivos na busca por novas legibilidades históricas. Em sua filmografia, Panh também sustenta o que designamos de lacunaridade da imagem - tal dimensão ontológica é acolhida e trabalhada de modo criativo, levando o espectador a entendê-la como uma opacidade inevitável (e como uma especificidade do suporte), em vez de ser encarada como um problema a ser driblado ante o desejo de uma construção biográfica total ou de uma restituição dos eventos passados.

Observemos uma obra em particular, o documentário A imagem que falta (2013). Como demonstra o cineasta, a partir do sugestivo título, essa ausência ou incompletude que alguns identificam como déficit precisa ser sentida e valorizada para melhor nos obrigar (a nós, espectadores) a um exercício do pensamento - a entender os vínculos possíveis entre cinema e história, imagem e testemunho. E no caso desse filme, que aborda a inexistência de registros sobre o genocídio ocorrido no Camboja nos anos de 1970, durante o regime do Khmer Vermelho ${ }^{10}$, a compreender o porquê dessa falta (a entendê-la como parte do esforço de

9 Digamos, pois, que, na condição de espectadores, a montagem deveria nos convidar a pensar em vez de pensar por nós. Do contrário, suas escolhas e gestos apenas atestariam o pensamento do diretor/montador, sem nos engajar criticamente na obra.

10 Designação atribuída aos seguidores do Partido Comunista da Kampuchea, que governou o Camboja de 1975/1979, de forma autoritária e promovendo execuções, expurgos e a tortura de adversários. Suas ações provocaram um genocídio responsável pela morte de até $20 \%$ da população. 
apagamento perpetrado pelo regime). Em síntese, Panh não pode, e não deve, nos fornecer um suprimento imagético ou contornar o que alguns julgariam como "insuficiência" porque precisamos entender a falta (a destruição ou a inexistência dos registros) como parte da operação genocida que vitimou o seu povo. Negligenciar essa lacuna implicaria em minimizar a contundência do extermínio, que visou igualmente o apagamento de qualquer prova. Em outros termos, nessa obra, o diretor nos convida a pensar que os regimes autoritários se caracterizam pela tentativa de mascarar a história e de ocultar as atrocidades por eles cometidas; e que a primeira tarefa importante nessa reflexão é identificar tal esforço em vez de contorná-lo - se os arquivos inexistem ou são escassos, que o espectador seja obrigado a ponderar o porquê desse apagamento ou escassez ${ }^{11}$.

Passemos agora aos títulos que indicamos como contraexemplos. Comecemos por Ônibus 174 (2002), de José Padilha. Ao costurar duas narrativas que se entrelaçam, o filme é uma espécie de investigação sobre a trajetória trágica de um menor que, uma vez adulto, se vê envolvido num sequestro com transmissão midiática; ou seja, a obra nos revela o seu histórico de abandono familiar e criminalidade precoce, mas também revisa o "assédio" jornalístico em torno do sequestro, respeitando sua cronologia agônica (da invasão do ônibus por Sandro, o jovem em questão, até a ação policial que resultou na morte do sequestrador e de Geísa Gonçalves, uma das reféns) ${ }^{12}$. Na última sequência do documentário, porém, notamos uma intervenção estilística ostensiva de José Padilha e do montador nos arquivos que recapitulam o desfecho da ação policial ${ }^{13}$. O que buscaria o diretor com tal operação?

Vejamos. Nos instantes finais do sequestro, quando Sandro sai do ônibus com Geísa, observamos que o cerco policial se intensifica, a cobertura midiática se adensa, tiros são disparados e duas mortes são registradas (a dele e a da refém). A montagem do documentário, como que evocando os apontamentos de Pasolini sobre o filme imaginário que nos daria ver a morte de Kennedy (uma compilação de planossequências), repete vários ângulos do evento (ou seja, diferentes "pontos de vista"), ao mesmo tempo em que interfere nos registros - desacelera, reprisa, faz a imagem retroagir, insere sons e intercala os arquivos com depoimentos que analisam a conclusão do episódio (opiniões que, em sua maior parte, elogiam o cerco policial).

Mas como ponderar essa montagem em looping de um acontecimento fatídico? Padilha desejaria aqui restituir o episódio na íntegra, nos dando a ilusão de uma "visão total"? Diferentemente dos títulos que empregam os arquivos com parcimônia, não creio que o diretor busca, nesse exercício, encontrar sentidos não manifestos ou novas legibilidades nas imagens. Ao contrário, ao travar uma espécie de embate com os arquivos (recusando sua opacidade), acreditando poder ver mais a partir da manipulação frequente, intuímos que Padilha termina por reduzir a intensidade do episódio, além de ceder ao que identificaremos à frente como uma demanda do espectador contemporâneo por uma visibilidade total. Afinal, repetir o evento é, antes de tudo, esvaziá-lo da sua condição de acontecimento, implica em banalizá-lo. Como dissemos antes: as operações cinemáticas abusivas não conferem às imagens um suprimento adicional de informações.

\footnotetext{
11 No filme, Panh utiliza imagens de arquivo evocativas da vida no Camboja antes e durante o regime do Khmer Vermelho, mas não registros do extermínio em si (posto que são inexistentes). Ao manusear os arquivos, o diretor faz algumas observações na banda sonora, mas não desfigura as tomadas, respeitando sua fenomenologia. E quando o relato pessoal predomina no documentário, num esforço para rememorar a trajetória de sua família, estilisticamente Panh opta por reencenações com pequenos bonecos em cenários estilizados - uma forma, talvez, de figurar sua memória. Tal recurso, contudo, não pretende substituir a ausência dos arquivos e tampouco mascara sua condição de artifício para o espectador.

12 Designado na crônica policial e na mídia de "sequestro do ônibus 174", o episódio em questão ocorreu em 12 de junho de 2000 , no Rio de Janeiro.

13 Em termos de decupagem, a sequência pode ser visionada no trecho que vai de $1 \mathrm{~h} 44 \mathrm{~m} 09 \mathrm{~s}$ a $1 \mathrm{~h} 49 \mathrm{~m} 16 \mathrm{~s}$, sendo o h empregado para horas, o m para minutos e o s para segundos.
} 
Apenas como referência, lembremos que, num filme célebre, Antonioni já nos indicara que a ampliação de uma imagem não a torna menos opaca (ou a aparta de suas ambiguidades) e tampouco nos leva a ver mais $^{14}$. Além disso, poderíamos sugerir que a montagem de Padilha também violenta o espectador com a reprise contínua de uma morte que já fora televisionada. Em contrapartida, questões relevantes ao episódio são secundarizadas no documentário: quem matou Geísa de fato e como Sandro morreu na ambulância teria sido uma espécie de justiçamento policial? Também é pouco enfática a crítica ao cerco midiático que transformou o sequestro em espetáculo, dificultando a ação policial, mas também prologando a agonia dos reféns (lembremos que Sandro, tantas vezes invisibilizado pela sociedade, ao perceber a onipresença das câmeras, finalmente se percebe protagonista).

Avancemos para o filme de Peter Jackson. Em Eles não envelhecerão (2018), o diretor compila registros diversos da I Guerra Mundial, intercalando a montagem do material com o depoimento de exsoldados britânicos. Organizados por afinidade temática, os testemunhos ${ }^{15}$ privilegiam a progressão dos eventos. De início, os arquivos imagéticos despontam num enquadramento menor do que a tela, tendo a mudez dos registros e o preto e branco preservados. Após 25 minutos, as tomadas se expandem e passam por forte intervenção: sofrem sonorização (ouvimos ruídos, risadas, falas e comandos "oriundos" do front, além de tiros e explosões), colorização, ralenti e mesmo certa interferência digital na fisionomia de alguns combatentes $^{16}$. Na banda sonora over, continuamos a ouvir os depoimentos dos veteranos. Porém, não obstante a intervenção severa e algo ingênua (que deseja nos comunicar a cor do inverno na relva francesa em 1916, o timbre da voz de um soldado, seus gritos diante do horror e até manifestações de saudade - algo irrecuperável e que no filme deveria despontar no máximo como sugestão $\left.{ }^{17}\right)$, o documentário apresenta outro problema que atestaria a pouca criatividade do cineasta para manusear seu achado arquivístico: na obra, a imagem permanece subordinada aos depoimentos; é praticamente empregada para ilustrá-los. Ou seja, Jackson não busca nos registros um algo a mais que permanecera latente ou sentidos que escapam às falas. As tomadas são apenas complemento. Em outros termos, podemos nós, espectadores, acompanhar o filme apenas pelos depoimentos, sem perdas no seu entendimento.

A série da BBC, Auschwitz - Os nazistas e a solução final (2005), a princípio, teria os ingredientes para ser excluída da lista de obras cujos procedimentos contestamos aqui. Afinal, contou com a consultoria de especialistas, foi dirigida por um pesquisador de prestígio (Laurence Rees) e tenta ser fiel aos fatos abordados. No entanto, também apresenta limitações. A primeira delas se enquadra no que poderíamos descrever como certa estetização do campo de extermínio: no decorrer da série, a paisagem do lager - seus sítios históricos não raro é filmada com esmero e o emprego de uma paleta de cores que conferem ao seu exterior a aparência de cartão postal. o risco evidente em tal recurso é o de aliviar o horror que o espectador deveria sentir, substituindo-o por uma imagem confortante, bucólica: somos, assim, tocados pela beleza da vegetação, pela luminosidade do poente ou pelas "flores de neve" petrificadas nos arames farpados ${ }^{18}$.

\footnotetext{
14 Referimo-nos, evidentemente, à obra Blow-up - depois daquele beijo (1966).
}

15 Os depoimentos são oriundos do acervo do Imperial War Museum.

16 As intervenções ocorrem a partir da minutagem indicada e, doravante, permanecerão no filme.

17 Por vezes, Jackson e sua equipe atribuem diálogos a soldados que, no enquadramento, são vistos de costas - decisão que desfaz o argumento de que uma possível leitura labial permitiria na contemporaneidade a recuperação de suas falas. Afinal, como ler os lábios de um rosto não visível na tomada? Assim sonorizado, o documentário se converte em logro sancionado pelo cineasta.

18 Sobre esta questão (o esforço para converter o lager num lugar turístico e tolerável ao olhar, no qual o constrangimento das selfies é amenizado e a venda de souvenires, aceitável), indico a reflexão de Didi-Huberman em Cascas (2017), espécie de obra complementar a Imagens apesar de tudo. 
A mais grave, porém, é seu descrédito perante a imagem e o arquivo (em sua capacidade de testemunho), o que levou a equipe a abraçar aquilo que, no presente, designamos como um regime de visibilidade total: uma tentativa de "dar a ver tudo" ao espectador e que, no limite, ambicionaria a restituição integral dos eventos passados. Assim, em vez de ponderar a lacunaridade dos registros, levando o espectador a entender a falta como uma operação do genocídio (algo que Pahn fizera de modo exemplar), a série da BBC opta pelo caminho oposto, combinando imagens de arquivo, cenas de reconstituição, testemunhos filmados, um retorno aos sítios históricos e o emprego do digital para reconstruir as instalações destruídas (sobretudo, as câmaras de gás de Treblinka e Birkenau). Em outros termos, a categoria do visivel é sempre julgada insuficiente, demandando informações adicionais. "Cada um desses regimes de imagens socorre o outro do qual ele finge suprir as lacunas, em particular do documento de arquivo", observa a historiadora Sylvie Lindeperg, ao comentar a mesma produção. E complementa:

É preciso dizer que esse filme tem por vocação levar ao conhecimento do grande público o mais preciso saber historiográfico e que esse saber se estende ao campo da imagem. No caso desse programa, as imagens estão corretamente legendadas e cuidadosamente reconstituídas em seu contexto. No entanto, os diretores não têm nenhuma confiança no poder intrínseco delas. Essas imagens têm que ser, então, completadas, sobretudo pela ficção, que vem suprir o fora de campo, preencher as lacunas e os vazios da imagem. [...] O filme pretende se inscrever na posteridade de "Shoah". Mas estamos aqui bem distantes do gesto de Lanzmann. A paisagem não é percorrida para falar da falta, da distância, da destruição das marcas, mas para designar o lugar onde o cenário será reimplantado graças às imagens digitais. A técnica digital permite reconstruir as instalações homicidas e colocar o espectador no interior da câmara de gás como num videogame. E mais, ao final desse passeio virtual, a porta se fecha sobre o espectador, que fica dentro da câmara de gás. No centro desse buraco negro que a ficção hesitou em representar ${ }^{19}$, o espectador se encontra num lugar impossivel onde ele não pode estar. Neste tipo de operação, o fora de campo desaparece para dar lugar a um planocheio, a uma estética do super-visivel que corresponderia à economia televisiva atual (COMOLLI; LINDEPERG, 2010, p. 333, grifos do autor).

No entanto, reiterarmos nossa inquietação com o tema central deste ensaio, ao revisar os argumentos e a perplexidade de Lindeperg (2015) diante de um projeto semelhante, a série Apocalipse - A Primeira Guerra Mundial (2014), e o debate que ele impulsionou na imprensa francesa.

Segundo ela, uma vez que o digital facilita a manipulação dos arquivos audiovisuais, ele nos colocaria um desafio ante a possibilidade de elaboração de novos saberes históricos a partir dos registros do passado. Retocado, o arquivo perderia seu apelo historiográfico, convertendo-se em artefato espetacular repaginado pela indústria cultural. Portanto, convém na atualidade mensurar as contradições engendradas por esse emprego desprovido de rigor. O mais surpreendente, porém, é constatar que tais distorções despontariam mesmo nas obras que pretendem articular um conhecimento legítimo. "Cada época", acrescenta Lindeperg (2015, p. 18), "projetou sobre as imagens do passado seus sonhos e fantasmas, violentou-as sem limites". Caberia à nossa geração, portanto, avaliar o tipo de violência facultada pelo digital.

Para Lindeperg (2015), os arquivos imagéticos sempre se viram acuados entre duas ameaças: o da interpretação equivocada de um passado que retornaria na íntegra (uma confiança na transparência do registro); e o comentário abusivo que exige que a imagem "confirme" as demandas do investigador e do seu tempo. Assim, ela nos diz, é tarefa dos historiadores e documentaristas ponderar a dialética entre visibilidade e legibilidade em jogo na imagem em movimento. Cuidado que exige um conhecimento das técnicas de filmar, uma reflexão sobre o contexto de origem das tomadas (em que condições foram 
produzidas e em atendimento a quais anseios) e suas relações com o extracampo - afinal, o que é visível numa tomada não é apenas o que consta no quadro e qualquer alteração indevida "apagaria" também as condições enfrentadas pelo cinegrafista.

É fato que, no passado e em virtude da inexistência de um conhecimento maduro sobre as imagens e os eventos históricos em si, alguns filmes incorreram em equívocos na retomada dos arquivos. Mas hoje, quando esse saber se revela abrangente, insiste Lindeperg (2015), a repetição de tais desvios é inaceitável. Portanto, seria preciso retificar o epíteto histórico atribuído aos títulos que insistem nessas distorções. Afinal, como podemos falar de verdade histórica nas obras onde os arquivos são alterados e suas determinações técnicas e ideológicas distorcidas?

Para Lindeperg (2015), essa desfiguração visaria atender a certa economia do visível para a qual o manuseio cauteloso dos arquivos não é prioridade. Ela reforça sua argumentação ao cotejar o debate que se seguiu na imprensa francesa à divulgação da série Apocalipse (2014), produção que recupera e introduz efeitos diversos nos registros da 1a Guerra Mundial. Conduzido com má fé, o embate opôs, de forma caricatural, os "antigos" - os acadêmicos "guardiões ortodoxos do preto e branco" - aos "modernos", os adeptos do progresso, convencidos das virtudes do digital; e terminou por mascarar os abusos da manipulação ao silenciar as vozes discordantes.

Para os "modernos", a colorização seria um must tecnológico a serviço de um "maior realismo" e o digital "corrigiria" as limitações das imagens em preto e branco. Assim, em nome de um discurso tecnicista, a lacunaridade da imagem e as especificidades do suporte são transformados em problema a ser contornado; no limite, a distorção tecnológica almejaria igualar o "real" (o evento em si) ao seu registro, recalcando o fato de que o registro, por natureza, é sempre um recorte parcial.

Em outros termos, ao alterar as tomadas do passado, a equipe da série termina por produzir uma imagem falsa, apagando as escolhas daqueles que lidaram com um determinado suporte e com restrições diversas, como filmar numa situação de conflito. A montagem indiferente dos arquivos eliminaria também a distinção entre os registros profissionais e amadores, ou entre as imagens institucionais (de propaganda) e o material jornalístico, impondo uma falsa continuidade entre tomadas concebidas sob diferentes motivações ${ }^{20}$. Tal montagem mantém os espectadores na ilusão de que "todos" os acontecimentos do passado teriam sido filmados - escolha que, no limite, visa atender aquilo que designamos como uma demanda por visibilidade total da contemporaneidade. O problema é resumido de modo exemplar por Lindeperg (2015, p. 23): segundo ela, essa manipulação que nega os aspectos técnicos e a historicidade das eras do visivel, ao uniformizar os registros, "apenas reanima a ilusão de um passado recuperado em sua completude, ampliando a confusão entre o acontecimento e o seu registro filmado". Para seus entusiastas, "as imagens do passado não são consideradas como testemunhos, ou pontos de vista sobre o mundo", mas como "a realidade visivel das coisas, a verdade da própria história na medida em que aparecem como evidência na tela".

Assim "modernizada", a obra final apresentaria "uma espécie de rosto esticado pela plástica das técnicas digitais", com cada episódio propondo ao espectador "um mergulho livre na imagem e no som, uma montagem agitada e veloz que pulveriza a duração dos planos, uma visão do passado governada pelos afetos e sentidos presentes" (LINDEPERG, 2015, p. 24). Ou, como sugere Comolli (2007), trata-se de uma edição que atende tão somente às demandas contemporâneas por celeridade, cintilação e fragmentação, fomentando no espectador um olhar impaciente, que não mais aceita demorar num plano e se engajar criticamente à obra. E, no que se refere à "economia dos arquivos", Lindeperg (2015) aponta outro problema: ao violar

20 Em diálogo com a historiadora, podemos refletir sobre os riscos evidentes no livre encadeamento de arquivos heterogêneos. Sem atenção a qualquer referencialidade, as imagens se converteriam em um catálogo de planos indistintos à disposição do realizador e onde todos os registros adquirem o mesmo estatuto, não obstante suas diferenças. Em outros termos, o trabalho de ressignificação, quando norteado pelo desejo de investigação histórica, não deve tratar o acervo audiovisual como livre "peça de montagem". 
as imagens do passado, seus diretores estariam produzindo "arquivos imprecisos" para a geração futura (documentos que, uma vez consultados, suscitarão leituras equivocadas). Por fim, ela conclui: "devemos lembrar que a conquista do público não pode ser obtida por meio do maltrato das imagens e do desprezo pela História" (LINDEPERG, 2015, p. 26)21.

Do recorte fílmico indicado, reservamos para o final deste ensaio o documentário Democracia em vertigem (2019), de Petra Costa, que analisa o contexto político brasileiro recente, marcado por uma forte polarização, e que culminou no impeachment de Dilma Rousseff (PT), em 2016, e na eleição de Jair Bolsonaro à presidência, em 2018. Tal decisão encontra duas justificativas: a polêmica suscitada pelo filme decorre de um único plano, na verdade do emprego de uma fotografia ${ }^{22}$; e, diferentemente das obras anteriores, marcadas por um esforço para suprir a insuficiência do arquivo, obrigando-o a falar mais, no documentário de Petra, o retoque digital buscou reduzir as informações originalmente presentes no quadro, ainda que a intenção da diretora, a priori, transpareça alguma honestidade.

A imagem em questão é um registro em preto branco, no qual observamos dois homens mortos. Uma das vítimas é o jornalista Pedro Ventura Felipe de Araújo Pomar, 63 anos, companheiro de militância dos pais de Petra. Na foto, ele se encontra de barriga para cima, óculos de grau no rosto, descalço e com o corpo coberto de sangue. Aos seus pés, de bruços, avista-se Ângelo Arroyo, de 48 anos, a segunda vítima. Dirigentes do Partido Comunista do Brasil (PCdoB), a dupla fora executada na manhã do dia 16 de dezembro de 1976 pelas forças policiais do Estado, na capital paulista, no episódio que ficou conhecido como a Chacina da Lapa ${ }^{23}$.

Quando comparada com a fotografia original, arquivada no Instituto de Criminalística de São Paulo, percebe-se que, na imagem empregada no filme, foram apagadas digitalmente duas armas posicionadas junto aos corpos dos militantes. Em depoimento à revista Piauí, Petra diz que aguardava a manifestação de alguém do público para que pudesse esclarecer a decisão. Segundo a diretora, uma vez que a polícia do regime adulterava o cenário de suas ações para justificar qualquer abordagem, ela optara pela intervenção como forma de "homenagear a Pedro com uma imagem mais próxima à provável verdade" (COELHO, 2019), posto que a imagem do jornalista morto ficara marcada pela presença das armas junto ao seu corpo. 0 retoque, ela insiste, fora uma oportunidade para retificar o equívoco.

Em outros termos, se trata de uma manipulação para corrigir outra manipulação. Ainda que conduzida por boa-fé, sua decisão não é desprovida de polêmicas. Primeiramente, a intervenção não é mencionada no filme ou em qualquer outra fonte facilmente acessivel; assim, não fosse o posicionamento de alguns especialistas, o apagamento passaria despercebido. Por outro lado, em se tratando de uma fotografia cuja cena fora manipulada com a intenção de burlar a verdade de uma chacina, um procedimento que nos parece historicamente mais instigante teria sido o de exibir a imagem original, com o "teatro forjado", e de dedicar a ela um tempo maior na montagem, revelando a falsificação como estratégia comum do poder repressor (uma tentativa de validar a abordagem policial e de deslegitimar a ação política das vítimas). Em outros termos, pensar com a imagem e demandar igualmente uma reflexão do espectador.

21 A abordagem de Lindeperg encontra convergência com o debate articulado por Baron (2014) no capítulo 2 de seu livro The archive effect Found footage and the audiovisual experience of history, com pequenas diferenças. Em sua investigação sobre a manipulação dos arquivos, o autor demonstra maior preocupação com a experiência espectatorial - como o espectador lidará com tais registros desfigurados ou erroneamente contextualizados; já Lindeperg (2015) investiga o impacto desse artifício na produção de saberes históricos (como a circulação de arquivos adulterados estimularão entendimentos enviesados no futuro). Mas o julgamento de ambas é similar, manifestando inquietação com tal prática. Se em nossa revisão priorizamos o texto de Lindeperg é tão somente pela similaridade do corpus fílmico analisado.

22 o referido plano desponta pouco depois dos $6 \mathrm{~m}$ de visionamento da obra.

23 A manipulação da fotografia pela equipe do filme foi objeto de debate discreto na imprensa brasileira. Destacamos as coberturas da revista Piauí e da Folha de São Paulo, cujas informações utilizamos neste texto. Para mais detalhes, conferir: COELHO, Thiago. Memória desarmada. Revista Piauí, 30 jul. 2019. Disponível em: <https://piaui.folha.uol.com.br/memoria-desarmada/> Acesso em: 30 jul. 2020. PETRA Costa adultera foto e exclui armas em cena de 'Democracia em Vertigem'. Folha online, 30 jul. 2019. Disponível em: <https://www1.folha.uol.com.br/poder/2019/07/petra-costa-adulterafoto-e-exclui-armas-em-cena-de-democracia-em-vertigem.shtml>. Acesso em: 30 jul. 2020. 
Nesse exercício, a imagem retocada até poderia ser encaixada na edição, de modo a facultar um melhor entendimento do trabalho manipulativo. Tal abordagem, admitimos, corre o risco do didatismo se não for conduzida com sutileza; mas nos parece uma escolha mais prudente do que promover o embotamento da memória histórica contida no registro original ${ }^{24}$.

\section{Considerações finais - A economia do visível na contemporaneidade}

A partir do que foi discutido neste ensaio, gostaríamos de finalizar o texto com uma recapitulação do que identificamos como as duas características das formas de produção, circulação e consumo de conteúdo audiovisual na contemporaneidade. Tais práticas singularizam parte do regime imagético e nos ajudam a entender a economia do visivel na atualidade. Ao destacá-las, aludimos majoritariamente à produção cinematográfica, embora elas também despontem em outros suportes. E ao retomar tais questões, priorizamos um exercício de revisão que almeja estimular desenvolvimentos futuros.

Assim, é preciso delinear essas tendências e mapear suas implicações. Comecemos pelas escolhas de montagem. Pautemo-nos pelas observações de Comolli (2007). Ao refletir sobre o tema, sobre os engajamentos que a obra pode suscitar no espectador (de uma participação ativa a uma espécie de alijamento) em virtude da montagem adotada, o autor aponta como principal fardo de certa prática cinematográfica o que ele designa de "zapping generalizado", tendência decorrente da influência da publicidade, do videoclipe e do jornalismo. Ao emular na edição o gesto do zapeador, incorporando o jump cut, essa prática visa produzir efeitos de sentido (ou restringi-los) mediante o excesso de cortes no interior da cena e a condução enfática do olhar do espectador. E o que nos permitiria ver os filmes que cedem ao zapping? Pouco. Ou melhor, muitos arranjos e quase nada. Deparamo-nos com um encadeamento célere de planos que mesclam materiais heterogêneos. A mistura é atraente, mas o jogo não é gratuito: visa reduzir a alteridade (do mundo) à familiaridade do espetáculo. 0 efeito é o de uniformidade. Como aponta Comolli (2007), o espetáculo está em toda parte; o real, em nenhuma. Assim, é preciso problematizar essa aceleração do olhar do espectador e essa afirmação do poder da montagem que converte a tomada em cintilação volátil e que fomenta uma pedagogia deletéria. Afinal, o espectador que resulta dessa estética da abreviação é um sujeito marcado pela impaciência e febrilidade diante das imagens, alguém cujo olhar já não aceita durar e acompanhar um plano, e que se inquieta quando uma tomada se dilata, portando cargas de ambiguidades.

Passemos para a tendência aqui designada de violação dos arquivos. A partir dos exemplos fílmicos avaliados, verificamos que as tecnologias digitais também têm sido empregadas para promover uma manipulação indevida dos registros audiovisuais do passado. Assim, procedimentos como a colorização, a sonorização, o reenquadramento, a correção do que é considerado precário na tomada original e a junção indistinta de fontes heterogêneas parecem submeter os arquivos à sensibilidade ou às maneiras de ver do presente.

24 Durante sua circulação, o documentário foi alvo de outras polêmicas na imprensa: a supervalorização (ou idealização) da militância dos pais da diretora no contexto da ditadura militar; a pouca ênfase de Petra ao relatar a condição de sua mãe como herdeira do grupo empresarial Andrade Gutierrez; e a não explicitação da relação antiga entre sua família e o PT, sobretudo com a figura de Lula. Como referência, indicamos:

BASÍlIO, Astier. O fantástico mundo de Petra: como a diretora inventou um passado clandestino para os seus pais. Estado de São Paulo, 11. jul. 2019. O Estado da Arte (revista de cultura, artes e idéias). Disponivel em <https://estadodaarte.estadao.com.br/o-fantastico-mundo-de-petra-como-acineasta-inventou-um-passado-clandestino-para-seus-pais/>. Acesso em :30 jul 2020.

CARNEIRO, Fernando. Democracia em vertigem é honesto, mas ignora questões essenciais. Revista Época, 24 jun. 2019 . Disponível em: <https://epoca. globo.com/artigo-democracia-em-vertigem-honesto-mas-ignora-questoes-essenciais-23759475>. Acesso em: 30 jul. 2020.

FAMÍLIA de Petra Costa, de “Democracia em vertigem", tem elo antigo com a de Lula. Folha online, 3 jul. 2019. Disponivel em: <https://www1.folha.uol. com.br/poder/2019/07/familia-de-petra-costa-de-democracia-em-vertigem-tem-elo-antigo-com-a-de-lula.shtml>. Acesso em 30 jul. 2020. 
Os entusiastas da prática alegam maiores ganhos em termos de "realismo" e "poder de sedução" perante o espectador. Porém, como censura Lindeperg (2015), em nome de um discurso tecnicista, a lacunaridade da imagem é transformada em problema a ser contornado; no limite, a manipulação visaria igualar o evento em si ao seu registro, recalcando sua insuficiência constitutiva. Tais práticas, segundo ela, almejam atender a demanda por visibilidade total da contemporaneidade (o desejo de tudo filmar, de tudo mostrar, de tudo ver). Em outros termos, o passado é subjugado às reivindicações do presente, em termos de visibilidade, de retórica, de aparência, de velocidade de exposição e ritmo de edição.

Lindeperg (2015), no entanto, nos alerta para o risco de investirmos em construções sem margem para o fora de campo e para o exercício da imaginação; de validarmos um gesto que desconfia da imagem e que deseja suprimir uma falta incontornável, ao empregar procedimentos que distorcem a referencialidade do registro, despojando-o de sua condição de artefato histórico. Em síntese, o arquivo não deve ser acolhido como transparência; antes, deve ser encarado na sua opacidade, como um objeto gerado por um determinado poder e acompanhado de intencionalidades. Ele não deve ser sacralizado, nem recusado de antemão, mas problematizado e continuamente remontado. Em se tratando da imagem, a observação é igualmente válida: ela revelaria algo, ao mesmo tempo em que encobriria outras informações. Propriedade que Didi-Huberman (2015) astuciosamente designara de imagem-malícia. 


\section{Referências}

A IMAGEM que falta. Direção: Rithy Panh. França, 2013. 1 DVD (92min), color. Título original: L'image manquante.

AMIEL, Vincent. Estética da montagem. Lisboa: Edições Texto \& Grafia, 2011.

APOCALIPSE - A Primeira Guerra Mundial. Direção: Isabelle Clarke e Daniel Costelle. França, 2014. 1 DVD (240min), color. Título original: Apocalypse, la 1ère Guerre mondiale.

AUSCHWITZ - Os nazistas e a solução final. Direção: Laurence Rees. Inglaterra: BBC, 2005. 2 DVD (300min), color. Título original: Auschwitz: The Nazis and The Final Solution.

BARON, Jaimie. The archive effect - Found footage and the audiovisual experience of history. London/ New York: Routledge, 2014.

BENJAMIN, Walter. Magia e técnica, arte e política. 8 ed. São Paulo: Editora Brasiliense, 2012.

Baudelaire e a modernidade. Belo Horizonte: Autêntica editora, 2017.

BERNARDET, Jean-Claude. A migração das imagens. In: TEIXEIRA, Francisco Elinaldo. (Org.) Documentário no Brasil - Tradição e transformação. São Paulo: Summus, 2004.

BRUZZI, Stella. New documentary. 2 ed. London and New York: Routledge, 2006.

BUGLIOSI, Vincent. Reclaiming history - The assassination of President John F. Kennedy. New York: Norton \& Company, 2007.

BURKE, Peter. Testemunha ocular: História e imagem. Bauru: EDUSC, 2004.

COMOLLI, Jean-Louis. Algumas notas em torno da montagem. Revista Devires, Belo Horizonte, vol. 4, n. 2, p. 12-41, jul./ dez. 2007. Disponivel em: <http://www.fafich.ufmg.br/devires/index.php/Devires/issue/ archive>. Acesso em: 1 ago. 2020.

.; LINDEPERG, Sylvie. Imagens de arquivos: imbricamento de olhares. Entrevista com Sylvie Lindeperg. In: MAIA, Carla et al. (Orgs.). Catálogo do Forumdoc. Belo Horizonte: Filmes de Quintal/FAFICHUFMG, 2010.

DEMOCRACIA em vertigem. Direção: Petra Costa. Produção: Joanna Natasegara, Shane Boris eTiago Pavan. Brasil: Netflix, 2019. 1 vídeo (121 min), color.

DIDI-HUBERMAN, Georges. Cascas. São Paulo: Editora 34, 2017.

Diante do tempo. Belo Horizonte: EDUFMG, 2015.

Falenas - ensaios sobre a aparição. Lisboa: KKYM, 2015. 
Imagens apesar de tudo. Lisboa: KKYM, 2012.

EISENSTEIN, Sergei. A forma do filme. Rio de Janeiro: Jorge Zahar, 2002.

O sentido do filme. Rio de Janeiro: Jorge Zahar, 2002.

ELES não envelhecerão. Direção e produção: Peter Jackson. Inglaterra, 2018. 1 DVD (99 min), color. Título original: They Shall Not Grow Old.

FARGE, Arlette. 0 sabor do arquivo. São Paulo: Edusp, 2009.

LEYDA, Jay. Films beget films: A study of the compilation film. 1st edition. New York: Hill and Wang, 1964. LINDEPERG, Sylvie. O destino singular das imagens de arquivo. Revista Devires, Belo Horizonte, v. 12, n. 1, p. 12-27, 2015. Disponível em: <https://bib44.fafich.ufmg.br/devires/index.php/Devires/article/view/342>. Acesso em: 31 jul. 2020.

ÔNIBUS 174. Direção: José Padilha. Codireção: Felipe Lacerda. Brasil, 2002. 1 DVD (2h30min).

PASOLINI, Pier Paolo. Empirismo Hereje. Lisboa: Assírio e Alvim, 1981.

RASCAROLI, Laura. The personal camera: subjective cinema and the essay film. Nova York: Wallflower Press, 2009.

RENOV, Michael. The subject of documentary. Minneapolis: University of Minnesota Press, 2004.

SARLO, Beatriz: Tempo passado: cultura da memória e guinada subjetiva. São Paulo: Companhia das Letras; Belo Horizonte: UFMG, 2007.

WEES, William. Recycled images: The art and politics of found footage films. New York: Anthology Film Archives, 1993.

ZAPRUDER FILM. Direção: Abraham Zapruder. Estados Unidos, 1963. Filme de curta metragem (1 min.). 


\section{Informações sobre 0 artigo}

\section{Resultado de projeto de pesquisa, de dissertação, tese}

Não se aplica.

\section{Fontes de financiamento}

O ensaio foi desenvolvido durante o pós-doutoramento. Apesar de não corresponder ao projeto central da pesquisa, sua elaboração se deu durante esse processo. Assim, parece-me justo dizer que ele foi financiado pela Coordenação de Aperfeiçoamento de Pessoal de Nível Superior (CAPES), processo 88881.337031/2019-01 (Professor Visitante no Exterior Júnior - Edital no 01/2019 - Seleção 2019).

\section{Considerações éticas}

Não se aplica.

\section{Declaração de conflito de interesses}

Não se aplica.

\section{Apresentação anterior}

Uma versão preliminar e incipiente do texto foi apresentada no IV Colóquio Internacional de Cinema e História, realizado na UFPR (Curitiba-PR), entre os dias 3 e 6 de dezembro de 2019.

\section{Agradecimentos/Contribuições adicionais}

Não se aplica. 